https://doi.org/10.19195/0080-3626.63.2

JAKUB ŁUKASZEWSKI

\title{
O JANIE ŻDŻAROWSKIM I JEGO ZNAKU NOTARIALNYM UŻYTYM W NIETYPOWEJ FUNKCJI EKSLIBRISU
}

Ekslibris przypisywany w literaturze Wojciechowi Strzałkowskiemu, najstarszy tego rodzaju polski księgoznak odbijany za pomocą klocka drzeworytniczego na kartach książkowych, rzeczywiście należał do Jana Żdżarowskiego. Pierwotnie Żdżarowski używał klocka do wykonywania znaku notarialnego - to najstarszy taki przypadek z terenów Polski. Narzędzie wykonano około 1517-1518 roku, na pewno przed 26 stycznia 1519 roku.

SŁOWA KLUCZOWE: znak notarialny, ekslibris, klocek drzeworytniczy, Jan Żdżarowski, Wojciech Strzałkowski, stare druki, inkunabuły

W świetle dotychczasowych ustaleń badaczy po ekslibrisach Macieja Drzewickiego $^{1}$ najstarszym tego rodzaju polskim znakiem książkowym jest ekslibris przypisywany Wojciechowi Strzałkowskiemu, notariuszowi konsystorza gnieźnieńskiego, który datuje się na lata 1519-1520. Został on odkryty, opisany i opublikowany przez ks. Leona Formanowicza ${ }^{2}$. To jak dotąd najstarszy znany przykład znaku własnościowego odbijanego z klocka drzeworytniczego bezpośrednio na kartach książki, jak pisał Arkadiusz Wagner, łączącego „,cechy ekslibrisu i rozpowszechnionej w późniejszych epokach — pieczątki" "3. Przypisanie ekslibrisu Strzałkowskiemu utarło się bez dyskusji w literaturze ${ }^{4}$. Nie jest jednak właściwe.

${ }^{1}$ E. Chwalewik, Exlibrisy polskie szesnastego i siedemnastego wieku, Wrocław 1955, s. 12-16, il. 8-9; P. Pokora, ,,Pontificale Romanum” z 1520 roku z biblioteki prymasa Macieja Drzewickiego. O odnalezieniu jednego z zaginionych klejnotów Biblioteki Katedralnej w Gnieźnie, „Biblioteka” 17 (26), 2013, s. 37-51; A. Wagner, Prymas Maciej Drzewicki jako bibliofil. W pięćsetlecie powstania pierwszego polskiego ekslibrisu, Warszawa-Toruń-Poznań 2016.

2 L. Formanowicz, Katalog inkunabułów Biblioteki Katedralnej w Gnieźnie, z. 1, Poznań 1939, s. 49, nr 188, il. XI; por. E. Chwalewik, op. cit., s. 16-17, il. 21.

3 A. Wagner, Uwagi o znakach własnościowych z drugiej połowy XVI i pierwszej ćwierci XVI wieku w inkunabułach Biblioteki Uniwersyteckiej w Poznaniu, „Biblioteka” 17 (26), 2013, s. 32.

${ }^{4}$ E. Chwalewik, op. cit.; A. Wagner, Uwagi o znakach ...; J. Osięgłowski, Konserwacja ksiązki w Polsce przedrozbiorowej, Poznań 1985, s. 37; M. Grońska, Ekslibrisy: wiadomości zebrane dla kolekcjonerów, Warszawa 1992, s. 26; K. Skupieński, Notariat publiczny w średniowiecznej 
W niniejszym artykule wykażę, że ów znak należał do Jana Żdżarowskiego, notariusza publicznego, kanonika katedralnego poznańskiego, włocławskiego i krakowskiego (zmarłego w 1551 roku).

Jak dotąd najpełniejszy biogram Jana Żdżarowskiego przedstawili Wiesław Wydra i Rafał Wójcik ${ }^{5}$. Warto jednak uzupełnić go o kilka szczegółów. Żdżarowski urodził się w końcu XV wieku ${ }^{6}$ jako syn Wincentego ze Żdżarowitej ${ }^{7}$ herbu Poraj ${ }^{8}$ i Barbary Zakrzewskiej ${ }^{9}$, także Poraitki ${ }^{10}$. O jego edukacji nie mamy bliższych informacji1 ${ }^{11}$. Na pewno w styczniu 1519 roku rozpoczął pracę jako notariusz krakowskiego wikariusza in spiritualibus, Mikołaja z Bedlna. Admisja ${ }^{12}$ Żdżarowskiego, wraz ze znakiem notarialnym (o którym mowa w dalszej części tekstu), znajduje się w księdze czynności Bedleńskiego pod datą 26 stycznia $1519 \mathrm{roku}^{13}$. Z treści admisji dowiadujemy się, że Żdżarowski został kreowany notariuszem publicznym apostolica auctoritate przez komesa pałacu laterańskiego Mikołaja Czepla (Czepiela) ${ }^{14}$. Nie znamy dokładnej daty kreacji notarialnej

Polsce, Lublin 1997, s. 130, przyp. 6; I. Kachur, Z historii bibliotek renesansowych - dar Erazma z Rotterdamu dla arcybiskupa Jana Łaskiego, [w:] Książka dawna i jej wtaściciele, T. 2, pod red. D. Sidorowicz-Mulak i A. Franczyk-Cegły, Wrocław 2017, s. 29.

5 R. Wójcik, W. Wydra, Jana Żdżarowskiego, kanonika poznańskiego diariusz z lat 15321551, „Kronika Miasta Poznania” 2006, nr 4. Literackie przystanki, s. 45.

${ }^{6}$ Ibidem.

7 Obecnie Rybno Wielkie-Żurawita, gmina Kiszkowo (powiat gnieźnieński, województwo wielkopolskie).

${ }^{8}$ O wywodzie szlachectwa Jana Żdżarowskiego przed przyjęciem do kapituły poznańskiej zob. B. Ulanowski, Materyaty do historyi prawa i heraldyki polskiej, „Archiwum Komisji Historycznej" 3, 1886, s. 387, nr 304.

9 Małżonka Wincentego wzmiankowana imiennie w zapisce w księdze grodzkiej poznańskiej z 20 lutego 1529 roku; por. Poznań, Archiwum Państwowe, Księgi sądu i urzędu grodzkiego w Poznaniu, sygn. Gr. 16, k. 303v-304r. Rodzeństwo Jana omówili R. Wójcik i W. Wydra, op. cit., s. 45-48.

10 B. Ulanowski, op. cit.

11 Nie ma pewności, czy ten Jan jest tożsamy z Janem de Zdzar, który uzyskał bakalaureat sztuk w 1519 roku; por. Najstarsza księga promocji Wydziatu Sztuk Uniwersytetu Krakowskiego $z$ lat 1404-1541, wyd. A. Gąsiorowski, T. Jurek, I. Skierska, Warszawa 2011, nr 1519/45B.

12 Admisją nazywa się w polskiej literaturze „określenie czynności urzędowej, która polegała na dopuszczeniu notariusza ad exercendum officium tabellionatus na określonym terenie" K. Skupieński, Notariat publiczny w średniowiecznej Polsce, Lublin 1997, s. 100. Takim terenem bywał zazwyczaj obszar konkretnej diecezji; por. A. Gąsiorowski, Admisje notariuszy publicznych w Wielkopolsce u schyłku wieków średnich, [w:] Społeczeństwo Polski średniowiecznej, T. 5, red. S.K. Kuczyński, Warszawa 1992, s. 267.

${ }^{13}$ Kraków, Archiwum Kurii Metropolitalnej (dalej: AKMK), Acta Officialia 37 (dalej: AOff.), s. 665. Własnoręczny wpis admisyjny Żdżarowskiego dowodzi, że był on już biegłym pisarzem, dobrze znającym łacinę, a jego admisja charakteryzuje się rozbudowanym formularzem. Sądzę, że nim Żdżarowski został notariuszem, praktykował w jakiejś kancelarii kościelnej może w otoczeniu Mikołaja Czepla? O wykształceniu kandydatów na notariuszy publicznych zob. K. Skupieński, op. cit., s. 83 n.

14 O Mikołaju Czeplu zob. P. Dembiński, Poznańska kapituła katedralna schyłku wieków średnich. Studium prozopograficzne 1428-1500, Poznań 2012, s. 526 n.; H. Barycz, Czepiel (Cze- 
Żdżarowity, ale wiemy, że doszło do niej po śmierci papieża Juliusza $\mathrm{II}^{15}$, a przed zgonem Czepla, czyli między 21 lutego 1513 a 30 kwietnia 1518 roku$^{16}$. Żdżarowski był skrybą w kancelarii Bedleńskiego najprawdopodobniej do końca 1523 roku $^{17}$. Od czerwca 1525 roku Żdżarowski działał jako jeden z notariuszy w kurii biskupia poznańskiego Jana Latalskiego; pełnił tę funkcję w latach $1525-1530^{18}$. Od 1526 roku notowany był jako altarysta gnieźnieński ${ }^{19}$. Początkowo, dzięki przychylności Latalskiego, Żdżarowski uzyskiwał kolejne beneficja. W 1529 roku wzmiankowano go jako plebana w Buku i Wrociszewie (do 1530 roku) ${ }^{20}$, a od 1530 roku był plebanem w Troszynie ${ }^{21}$. W tym też roku dowodził szlachectwa przed poznańską kapitułą katedralną i został instalowany na kanonię fundi Glinka ${ }^{22}$. Dalszą karierę na dworze Latalskiego przerwała Żdżarowskiemu sprawa zabójstwa kapłana Jana Łukomskiego - prepozyta kolegiaty św. Jerzego na zamku gnieźnieńskim i plebana w Dolsku ${ }^{23}$. O zbrodnię oskarżono Jana Żdżarowskiego i jego brata, Andrzeja, a kanonik został wezwany przez biskupa poznańskiego do Rzymu ${ }^{24}$. Dzięki wsparciu biskupa krakowskiego Piotra Tomickiego Żdżarowski

pel) Mikołaj (1453-1518), [w:] Polski Stownik Biograficzny (dalej: PSB), T. 4. Chwalczewski JerzyDąbrowski Ignacy, Kraków 1938, s. 331-332; A. Lewicka-Kamińska, Renesansowy księgozbiór Mikołaja Czepla w Bibliotece Jagiellońskiej, Wrocław 1956.

15 Wynika to z treści admisji, której początkowe fragmenty oparte są na tekście instrumentu notarialnego z aktem kreacji Żdżarowskiego (por. K. Skupieński, op. cit., s. 100). W jej wstępnej formule opisane zostały okoliczności uzyskania przez Czepla godności komesa laterańskiego (28 czerwca 1506 roku z nadania papieża Juliusza II; por. Vetera Monumenta Poloniae et Lithuaniae, T. 2, wyd. A. Theiner, Roma 1891, s. 308-309, nr 336). Papież wzmiankowany został jednak w admisji (a więc i w dokumencie kreacyjnym) jako zmarły: „Julium divina providencia p i e m em or i e papam secundum [wyr. - J.Ł.]"; por. aneks.

16 H. Barycz, op. cit., s. 332.

17 AKMK, AOff. 37, s. 940; AKMK, AOff. 57, s. 1232 (wpis z 5 listopada 1523).

18 Żdżarowski był pisarzem Latalskiego na pewno od 25 sierpnia 1525 roku; por. Archiwum Archidiecezjalne w Poznaniu (dalej: AAP), Acta Episcopalia (dalej: AE), sygn. AE VII, k. 30v. Inne wydane zapiski wzmiankujące Żdżarowskiego to: Acta Capitulorum nec non Iudiciorum Ecclesiasticorum selecta, T. 2. Acta Iudiciorum Ecclesiasticorum Dioecesum Gneznensis et Poznaniensis (1403-1530), wyd. B. Ulanowski, Kraków 1902, nr 1788, 1804, 1819, 1825, 1829.

19 AAP, AE VII, k. 42r (zapiska z 2 lutego 1526).

20 AAP, AE VII, k. 114v (zapiska z 5 kwietnia 1529); por. J. Nowacki, Dzieje Archidiecezji Poznańskiej, T. 2. Archidiecezja Poznańska w granicach historycznych i jej ustrój, Poznań 1964, s. 459 , przyp. 8 oraz s. 537, przyp. 67.

${ }^{21}$ Ibidem, s. 507, przyp. 17.

22 K. Miaskowski, Kanonicy katedralni poznańscy instalowani w latach 1524-1532, „Przegląd Kościelny" 6, 1904, nr 34, s. 279-280.

23 Jan Łukomski został zabity krótko przed 29 kwietnia 1531 roku; por. również: Akta kapitut z wieku XVI wybrane, wyd. B. Ulanowski, T. 1, cz. 1. Akta kapituł poznańskiej i włocławskiej (1519-1578), Kraków 1908, s. 19, nr 49.

24 AAP, sygn. AE VII, k. 241v-242r (1 lipca 1532). Por. Acta Tomiciana, T. 14, wyd. W. Pociecha, Wrocław-Kraków 1952, s. 595-596, nr 396; s. 597, nr 398; s. 749-750, nr 489; oraz Acta Tomiciana, T. 15, wyd. W. Pociecha, Wrocław-Kraków 1957, s. 410-411, nr 299. 
nie musiał odbywać kosztownych podróży do Stolicy Apostolskiej i między 1533 a 1535 rokiem oczyścił się z zarzutów ${ }^{25}$. Od roku 1541 do 1543 pełnił funkcję prokuratora kapituły poznańskiej ${ }^{26}$. W kolejnych latach widzimy Żdżarowskiego w otoczeniu Andrzeja Zebrzydowskiego. Gdy Zebrzydowski został biskupem włocławskim, mianował Żdżarowskiego kanclerzem swej kurii (od połowy 1546 roku) ${ }^{27}$, a w 1547 roku Żdżarowita uzyskał scholasterię wolborską ${ }^{28}$. W 1546 roku (13 listopada) otrzymał prowizję na kanonikat kruszwicki (według Antoniego Fiutaka był prałatem-kantorem ${ }^{29}$. Po uzyskaniu przez Zebrzydowskiego biskupstwa krakowskiego Żdżarowski również tam pełnił funkcję kanclerza dworu biskupiego i został kanonikiem krakowskim ${ }^{30}$. Zmarł pod koniec 1551 roku $^{31}$.

Obecnie nie mamy dowodów na to, aby Jan Żdżarowski gromadził większe ilości książek ${ }^{32}$. Jak dotąd jedyny znany wolumin, o którym wiadomo, że należał do Żdżarowskiego, to wieloroczny kalendarz autorstwa Johanna Stöfflera na lata 1532-1552, wydany w Tybindze w 1532 roku $^{33}$. Identyfikacji właściciela (na pod-

25 Ibidem, T. 15, nr 285, s. 395-386; Acta Tomiciana, T. 16, cz. 2, wyd. W. Pociecha, Wrocław-Kraków-Poznań 1961, s. 136-137, nr 452; s. 138-139, nr 453; s. 265-268, nr 528; oraz Acta Tomiciana, T. 17, wyd. W. Pociecha, Wrocław-Kraków-Poznań 1966, s. 389-390, nr 293. Dodam, że po oskarżeniu o zabójstwo Łukomskiego Andrzej Żdżarowski, brat Jana, opuścił Żdżarowitę 26 kwietnia 1532 roku; por. Jana Żdżarowskiego, kanonika poznańskiego, diariusz z lat 1532-1551, wyd. R. Wójcik, W. Wydra, Poznań 2009, s. 15. Skądinąd wiadomo, że Andrzej znalazł się na Litwie, gdzie brał udział w wojnie z Wielkim Księstwem Moskiewskim (1534-1537), a po zakończeniu działań zbrojnych otrzymał od króla Zygmunta Starego list żelazny; por. Archiwum Główne Akt Dawnych, Metryka Koronna, MK 54, k. 140-140v (25 czerwca 1537).

${ }^{26}$ K. Lutyński, Kapituła katedralna w Poznaniu w XVI wieku. Organizacja i majątek, Poznań 2000, s. 217.

27 A. Tomczak, Kancelaria biskupów włocławskich w okresie księgi wpisów (XV-XVIII w.), „Roczniki Towarzystwa Naukowego w Toruniu” 71, 1965, z. 1, s. 65.

28 Acta Historica Res Gestas Poloniae illustrantia ab anno 1507 usque ad annum 1795, T. 1. Andrzeja na Więcborku Zebrzydowskiego Biskupa włocławskiego i krakowskiego korespondencyja z lat 1546-1553 z przydaniem Synodów r. 1547 i 1551, jako też innych dokumentów współczesnych, wyd. W. Wisłocki, Kraków 1878, s. 156, nr 322.

29 Jana Żdżarowskiego, kanonika..., s. 43; A Fiutak, Prałaci kanonicy kruszwiccy, Popowo Kościelne 1938, s. 131 (maszynopis), aczkolwiek badacz ten nie podał źródła tej informacji. Stanisław Chodyński podał, że Żdżarowski 15 stycznia 1548 roku został instalowany na kantorię włocławską, a 15 sierpnia 1550 z polecenia bpa Zebrzydowskiego oddana została mu również włocławska dziekania; por. S. Chodyński, Katalog prałatów i kanoników włocławskich, cz. 5. T-Z, Włocławek 1914, s. 1091-1092 [rkps; kopia z 1994 r. w zbiorach Biblioteki Seminarium Duchownego we Włocławku, bez sygn.].

30 A. Fiutak, op. cit.; AAP, AE X, k. 59r.

31 Jan Żdżarowski na pewno nie żył już 18 stycznia 1552 roku; por. AAP, AE X, k. 58v-60v.

32 Żdżarowskiego nie ma wśród włocławskich prałatów i kanoników, którzy posiadali książki; por. B. Iwańska-Cieślik, Aspekty badań nad księgozbiorami członków kapituły katedralnej we Włocławku, „Studia Włocławskie” 13, 2011, s. 198, aneks.

33 Ephemeridum [...] a capite anni redemptoris Christi MDXXXII in alios XX. proxime subsequentes, Tybinga: Huldenrich Mohart, 1531, in $4^{\circ}$, Biblioteka Uniwersytecka w Poznaniu, sygn. SD 6660 II.

ROCZNIKI BIBLIOTECZNE

ROK LXIII, 2019

(C) for this edition by CNS 
stawie zawartych w nim zapisków diariuszowych) oraz szczegółowego opisu tego zabytku dokonali R. Wójcik i W. Wydra ${ }^{34}$.

W tym miejscu pora wykazać, że drugim woluminem z księgozbioru Żdżarowskiego jest Formularium instrumentorum ad usum Curiae Romanae [Hagenau: Heinrich Gran, przed 17 VIII 1492?], in $4^{\circ}$ (ze zbiorów Biblioteki Katedralnej w Archiwum Archidiecezjalnego w Gnieźnie ${ }^{35}$ ). W inkunabule tym, jak nadmieniłem we wstępie, ks. L. Formanowicz odkrył wczesny znak własnościowy, odbity bezpośrednio z klocka drzeworytniczego na nieliczbowanej karcie 1a oraz folio CCXXIIa. Formanowicz słusznie zwrócił uwagę, że ekslibris ten przypomina swym kształtem znak notarialny, i przypisał go Wojciechowi Strzałkowskiemu. Dla jasności cytuję tu w całości krótki, ale treściwy wywód pióra tegoż badacza:

Na podstawie tego signum umieszczone są inicjały patrona, patronimiku i nazwiska właściciela exlibrisu, mianowicie na górnej kondygnacji S[anctus] A[dalbertus] M[artyr], na dolnej zaś I[ohannides] S[trzałkowski]. Wojciech Janowic Strzałkowski herbu Poraj występuje jako notariusz konsystorza gnieźnieńskiego z końcem roku 1519 i na początku następnego (AOG) ${ }^{36}$.

I tu należy się sprostowanie — rzeczywiście w latach 1519-1520 w księgach gnieźnieńskiego konsystorza odnajdujemy pisarza Wojciecha Strzałkowskiego. Nie był on jednak synem Jana, lecz Mikołaja, i legitymował się zupełnie innym znakiem notarialnym ${ }^{37}$. Tymczasem we wspomnianej księdze czynności wikariusza generalnego krakowskiego, Mikołaja z Bedlna, Jan Żdżarowski opatrzył swą admisję znakiem notarialnym odciśniętym za pomocą klocka, identycznego jak ten, za pomocą którego wykonano odbitki na kartach gnieźnieńskiego inkunabu-

${ }^{34}$ R. Wójcik, W. Wydra, op. cit.; Jana Żdżarowskiego...; R. Wójcik, W. Wydra, op. cit., s. 44-45.

35 Archiwum Archidiecezjalne Gniezno (dalej: AAG), sygn. Inc. 37. Adres wydawniczy tej edycji dotąd nie jest z całą pewnością ustalony; por. Incunabula quae in bibliothecis Poloniae asservantur, T. 1, moderante Alodia Kawecka-Gryczowa composuerunt Maria Bohonos et Elisa Szandorowska, Wratislaviae 1970, nr 2218, które podaje „[Strassburg: Georg Husner, ca 1497]”; z kolei Gesamtkatalog der Wiegendrucke, T. 9, Stuttgart 1991, nr 10213 (dalej: GW) określa adres wydawniczy następująco: ,[Hagenau: Heinrich Gran, um 1495]”. Jednakże w uaktualnianej wersji internetowej GW znajduje się informacja inkunabulisty Michała Spandowskiego, który w egzemplarzu z Biblioteki Narodowej w Warszawie odnalazł rękopiśmienną zapiskę dotyczącą początku pontyfikatu papieża Aleksandra VI, datowaną na 17 sierpnia 1492 roku, co pozwala sądzić, że edycję tę wydrukowano przed tą datą (por. https://www.gesamtkatalogderwiegendrucke.de/docs/ GW10213.htm, uwaga 2).

36 L. Formanowicz, op. cit.

37 Wojciech Strzałkowski, syn Mikołaja de Carszij, był admitowany jako notariusz imperiali auctoritate 17 stycznia 1520 roku; narysowany przez niego znak notarialny przedstawia położoną poziomo ostrzew z czterema sękami i wpisem: „Flos Florum”, nad ostrzewią widnieją dwa kwiaty (?), między którymi pionowo umieszczona została strzała na barku pierścienia (jak godło herbu Ogończyk); zob. AAG, sygn. ACons.GII, k. 119r. Dodam, że znana jest jedna księga z proweniencją W. Strzałkowskiego: Formulare Instrumentorum, Köln: H. Quentell, 1504, $4^{\circ}$ (AAG, sygn. BK 5605), i w niej Strzałkowski posłużył się wyłącznie wpisem własnościowym. 
łu. Rozmiar odcisków przy admisji i w inkunabule jest taki sam $-60 \times 32 \mathrm{~mm}$ u podstawy kompozycji ${ }^{38}$.

Inicjały $I S$ z odcisku trzeba więc uznać za zgodne z zapisem z admisji, czyli I[oannes] S[zdzarowski]. Pozostają rozwiązania inicjałów $S$ A M. Formanowicz czytał je jako Sanctus Adalbertus Martyr, co miałoby być odwołaniem rzekomego posiadacza znaku, Wojciecha Strzałkowskiego, do jgo patrona. Wiemy już, że nie Strzałkowski był właścicielem tego signum (choć nie można wykluczyć, że i Żdżarowski nawiązał inicjałami do świętego Wojciecha jako patrona archidiecezji i współherbowca). Proponuję tu jednak inny odczyt — S [ignum] A[uthenticum] M[eum]. Pierwotnie był to bowiem znak notarialny, którego właściwa funkcja polegała na uwierzytelnianiu dokumentów spisywanych przez Żdżarowskiego. Trzeba przy tym podkreślić, że wyjątkowym faktem było użycie klocka drzeworytniczego do wykonania znaku. $\mathrm{Z}$ tego, co obecnie wiadomo, to najstarszy jak dotąd znany taki przypadek z terenów Polski, ponieważ ówcześni notariusze powszechnie posługiwali się znakami rysowanymi ${ }^{39}$.

Inna kwestia to użycie przez Żdżarowskiego znaku notarialnego odciskanego z klocka drzeworytniczego także w funkcji księgoznaku. To również, o ile wiadomo, ewenement dla XVI wieku ${ }^{40}$. Choć w tym wypadku nie powinno

38 Według E. Chwalewika ekslibris ów miał mieć rozmiar $42 \times 22 \mathrm{~mm}$, to oczywista pomyłka, wynikająca $z$ tego, że badacz nie dotarł do oryginału i podał wymiary reprodukcji tego znaku, zamieszczonej w katalogu L. Formanowicza; por. E. Chwalewik, op. cit., s. 17, przyp. 30.

39 „Nie znamy u nas znaków barwnych, ani też nie udało się dostrzec śladów użycia szablonu, czy tym bardziej stempla" - K. Skupieński, op. cit., s. 172; por. M. Koczerska, De manu, signo et nomine, czyli o krakowskich notariuszach publicznych w późnym średniowieczu, [w:] Kultura średniowieczna i staropolska. Studia ofiarowane Aleksandrowi Gieysztorowi w pięćdziesięciolecie pracy, pod red. D. Gawinowej, S. Gawlasa, M. Koczerskiej, Warszawa 1991, s. 198, przyp. 35. Szablonu, klocka drzeworytniczego czy stempla nie używali w momencie admisji także notariusze admitowani w diecezjach gnieźnieńskiej i poznańskiej do końca XV wieku (por. A. Gąsiorowski, Notariusze publiczni w Wielkopolsce u schyłku wieków średnich. Katalog admisji w Gnieźnie i w Poznaniu 1420-1500, Poznań 1993, s. 8, przyp. 12) ani notariusze zarejestrowani w gnieźnieńskiej księdze admisji w latach 1501-1646 (AAGn, sygn. ACons.GII, k. 107r-186r). Warto zauważyć, że wśród południowoniemieckich notariuszy z przełomu XV i XVI wieku znamy tylko czterech, którzy posługiwali się klockiem drzeworytniczym; por. P.J. Schuler, Südwestdeutsche Notarszeichen. Mit einer Einleitung über die Geschichte der deutschen Notarszeichens, Sigmaringen 1978, s. 18-19, przyp. 41a oraz rys. 134, 419, 797.

40 Śląski notariusz Jacob Berlogius posługiwał się ekslibrisem (datowanym na 1590 rok), odbijanym z drzeworytniczego klocka, jednak według Ilse O’Dell nie był on jednak używany w funkcji znaku notarialnego; por. eadem, Deutsches und Österreichische Exlibris 1500-1599 im Britischen Museum, London 2003, s. 34 nr 49. O znakach notarialnych używanych w funkcji ekslibrisu w XVII-XVIII zob. K.E. Graf zu Leningen-Westerburg, Bibliothekzeichen Exlibris. Ein Handbuch für Sammler Bücher- und Kunstfreunde, Stuttgart 1901, s. 547-549; B. Müller, Notariatssignet und Exlibris, „Exlibriskunst und Graphik” 1989, s. 15-20. Na marginesie dodam, że formę znaku notarialnego ma pieczątka przypisywana humaniście Faustusowi Andrelinusowi, uważana czasem za najstarszy francuski ekslibris z przełomu XV i XVI wieku; por. A. Kolb, Ein

ROCZNIKI BIBLIOTECZNE

ROK LXIII, 2019

(C) for this edition by CNS 
to dziwić. Klocek - jako narzędzie - doskonale się do tego nadawał. Sam zaś odciśnięty znak odgrywał swą rolę jako signum wskazujące konkretną osobę — tu właściciela księgi: Jana Żdżarowskiego ${ }^{41}$.

Trudno z pewnością odpowiedzieć, ile czasu minęło od kreacji notarialnej Żdżarowskiego do admisji na notariusza w diecezji krakowskiej (kreacja nastąpiła na pewno między 21 lutego 1513 a 30 kwietnia 1518 roku). Jeszcze trudniej stwierdzić, kiedy i gdzie wykonano dla Żdżarowskiego klocek drzeworytniczy, z którego wyciskał znak notarialny i którego przynajmniej raz użył w roli księgoznaku (w inkunabule gnieźnieńskim). Porównanie stanu zachowania obydwu odbitek wskazuje, że ta z admisji wygląda na wykonaną mniej starannie. Świadczą o tym luka w zewnętrznej ramce dolnej podstawy (pod literą „,S”) oraz przetarcia na wstędze i inicjałach (il. 1). Przyczyn defektów odbitki z admisji mogło być kilka, na przykład bardziej już zużyty klocek, mniej dokładne nałożenie farby na klocek, rodzaj nośnika (inny papier). Pamiętajmy w końcu, że krakowską księgę wikariuszowską przez wieki wielokrotnie wertowano i przeglądano, a znajdująca się tam odbitka znaku Żdżarowskiego nosi ślady pokolorowania brązowym inkaustem ${ }^{42}$. Trudno więc jednoznacznie rozstrzygnąć, w jakiej kolejności wykonano odbitki, ale z uwagi na lepszy stan ich zachowania w inkunabule, uważam, że mimo wszystko wykonano je nieco wcześniej od odbitki przy admisji (a więc krótko przed 26 stycznia 1519 roku). Samo narzędzie sporządzono, jak sądzę, około 1517-1518 roku — pytanie: gdzie? Róża na znaku notarialnym Żdżarowity przypomina w sposobie modelunku (charakterystyczne szrafirunki) różę z drzeworytowego ekslibrisu Piotra Izdbieńskiego (zmarł w 1528 roku) ${ }^{43}$ (il. 2). Ponadto ozdobniki na bokach dolnego gradusu znaku

Exlibris des 15. Jahrhunderts? Zur Geschichte der ältesten fränzösischen Bücherzeichen, „Gutenberg-Jahrbuch" 36, 1961, s. 249-254; I. O’Dell, op. cit., s. 94, nr 431.

41 „Znak notarialny [...] ma charakter bardziej osobisty, ponieważ w przeciwieństwie do pieczęci nie można go ani pożyczyć (jak w razie carentia sigilli), ani odziedziczyć. W zakresie formy, choć także funkcji, znak notarialny wykazuje [...] wiele wspólnego z herbem, a zwłaszcza gmerkiem mieszczańskim" - M. Koczerska, op. cit., s. 198; por. K. Skupieński, op. cit., s. 172; zob. też ważne uwagi A. Wagnera, dotyczące między innymi powiązań funkcjonalnych pieczęci i superekslibrisów - idem, Superekslibris Polski. Studium o kulturze bibliofilskiej i sztuce od średniowiecza do połowy XVII wieku, Toruń 2016, s. 414-418.

42 Wiadomo, że księga ta była naprawiana i przeoprawiona „w bliżej nieznanym czasie”; por. E. Knapek, Akta oficjalatu i wikariatu generalnego krakowskiego do połowy XVI wieku, Kraków 2010, s. 173-174, 250.

${ }^{43}$ Piotr Izdbieński (zmarł 16 sierpnia 1528), notariusz publiczny, pisarz królewski, kanonik włocławski, brat Benedykta bpa poznańskiego; zob. Matricularum Regni Poloniae Summaria, wyd. T. Wierzbowski, cz. 4, T. 2, Warszawa 1912, s. 297, nr 13894; L. Dobrzyńska-Rybicka, Dwie wielkopolskie bibljoteki klasztorne, „Zapiski Muzealne” 1918, nr 2-3, s. 9, przyp. 1; s. 13, il. 12; oraz A. Wagner, Superekslibris polski, s. 423, il. 200 (autor, sugerując się reprodukcją znaku z pracy L. Dobrzyńskiej-Rybickiej, podał informację, jakoby litera „P” w tym ekslibrisie została „błędnie wyryta"; tymczasem jest to wynik lustrzanego odbicia reprodukcji tego znaku w tekście badacz$\mathrm{ki}$ - pomyłka ta została z resztą skorygowana w erracie do artykułów zawartych w numerze 2-3 „Zapisków Muzealnych”. na s. nlb. 58). Ekslibris Izdbieńskiego (rozmiar $51 \times 37$ mm) znajduje się 

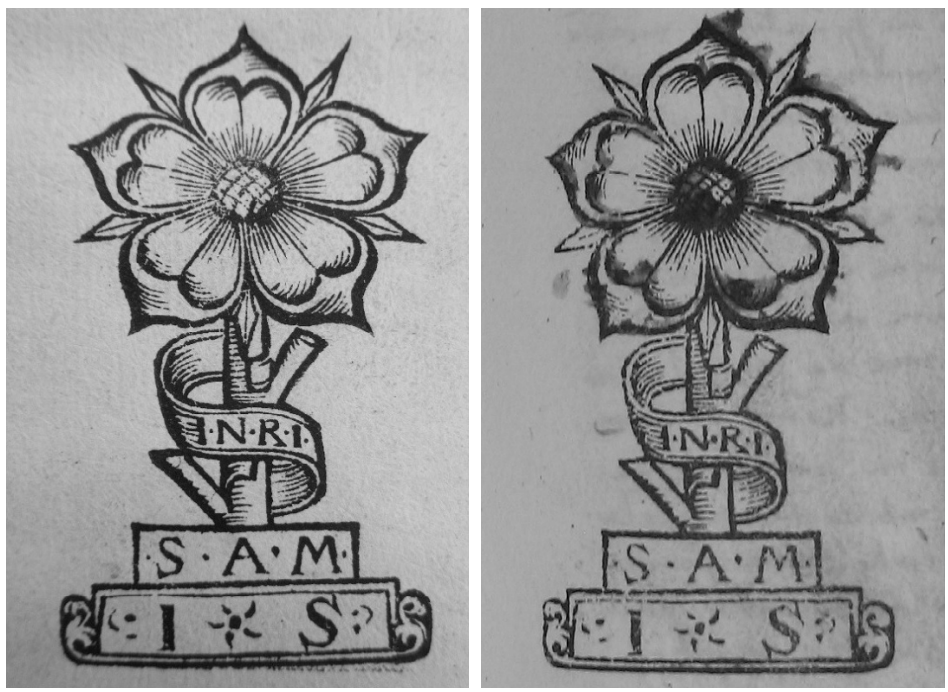

Il. 1. Po lewej: odbitka klocka drzeworytniczego ze znakiem notarialnym J. Żdżarowskiego, użytym w funkcji ekslibrisu (Gniezno, AAG, BK Inc. 37, k. nlb 1b - fot. J. Łukaszewski, (C) Archidiecezja Gnieźnieńska); po prawej: odbitka tegoż znaku przy wpisie admisyjnym (Kraków, AKMK, AOff. 37, s. 665, fot. J. Łukaszewski)

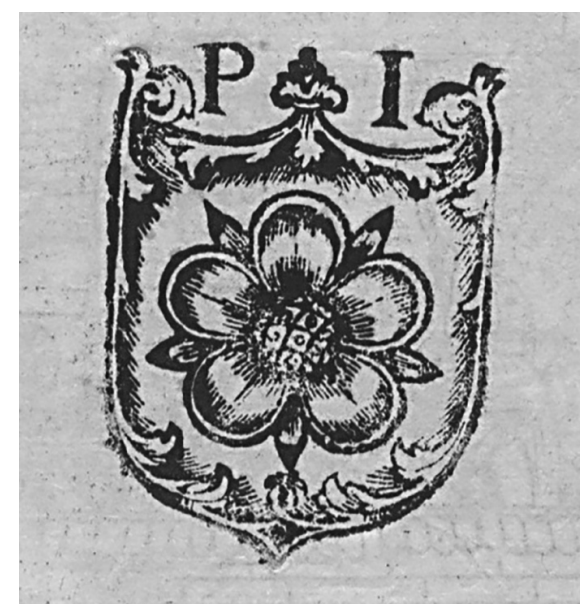

Il. 2. Ekslibris Piotra Izdbieńskiego (Johannes Chrysostomus,

Index in Quinque Tomos operum..., Basel: A. Cratander, 1522, 2º, Poznań, Biblioteka PTPN, sygn. 47941, T. 3, k. tyt. verso, fot. W. Graś)

Żdżarowskiego wykazują pewne podobieństwa do wykończeń boków italianizującej tarczy herbowej z księgoznaku Izdbieńskiego. Sądzę, że obydwa klocki drzewo-

między innymi w trzech woluminach w zbiorach Biblioteki Poznańskiego Towarzystwa Przyjaciół Nauk, sygn. 47941IV, wol. 1-3, i rzeczywiście ma prawidłowo ryte inicjały „P I”. 
rytnicze, którymi posługiwali się Żdżarowski i Izdbieński, powstały w tym samym, przypuszczalnie krakowskim, warsztacie ${ }^{44}$.

Inkunabuł, w którym Żdżarowski odbił znak, był na pewno w jego rękach na początku lat 20. XVI wieku. Wskazują na to trzy rękopiśmienne zapiski jego ręki. Ich treść i datowanie (1520-1523; sprzed 1524 roku; 23 listopada 1523 roku) dowodzą, że Żdżarowita posługiwał się tym zbiorem formularzy już w Krakowie, w kancelarii Mikołaja z Bedlna ${ }^{45}$.

Podsumowując, należy w świetle dokonanej analizy stwierdzić, że znak uważany dotąd za ekslibris Wojciecha Strzałkowskiego, notariusza konsystorza gnieźnieńskiego, należał faktycznie do Jana Żdżarowskiego. Jest to znak wyjątkowy z kilku względów. Jak wykazałem, przede wszystkim pierwotnie pełnił funkcję znaku notarialnego, ale odbijanego za pomocą specjalnie przygotowanego drzeworytniczego klocka. Jest to pierwszy poświadczony fakt umieszczania znaku tą metodą przez notariusza z terenów Polski. Klockiem tym, krótko przed 26 stycznia 1519 roku, Żdżarowski oznaczył inkunabułowe wydanie Formularium instrumentorum ad usum Curiae Romanae (obecnie w zbiorach gnieźnieńskiego Archiwum Archidiecezjalnego). Trudno powiedzieć, co zachęciło Jana Żdżarowskiego do takiego działania. Mógł to być oczywiście wpływ miłośników książek i humanistów, takich jak Mikołaj Czepiel, Piotr Tomicki, Andrzej Krzycki czy Jan Latalski (z którymi Żdżarowita był związany), którzy ozdabiali swe księgi superekslibrisami ${ }^{46}$, a Krzycki, od 1523 roku, ponadto drzeworytowym ekslibrisem, odbijanym z klocka bezpośrednio na kartach książkowych ${ }^{47}$. Najpewniej jednak to sam fakt posiadania wyjątkowego i użytecznego drzeworytniczego klocka ze znakiem notarialnym skłonił zaradnego kleryka do prekursorskiego użycia go także w roli księgoznaku ${ }^{48}$.

44 A. Wagner, Superekslibris polski, s. 423 sugeruje, że ekslibris P. Izdbieńskiego wykonano „prawdopodobnie” w Krakowie.

45 Na przedniej karcie ochronnej tej księgi Żdżarowita wpisał niedatowany formularz instrumentu notarialnego, w którego treści odnajdujemy nazwisko Paulusa de Planca, tytułowanego tam między innymi jako strenuus et egregius... miles. Wskazywałoby to, że wzorcem dla tego odpisu był dokument wystawiony między lipcem 1520 a 1523 rokiem (Paulus de Planca uzyskał tytuł militis Sancti Petri 20 lipca 1520 roku, a zmarł w 1523; por. T. Frenz, Die Kanzlei der Päpste der Hochrenaissance (1471-1527), Tübingen 1986, s. 422, nr 1824). Pozostałe dwie zapiski to: niedatowany formularz litterae dimisoriae, wystawionej przez biskupa krakowskiego Jana (Konarskiego) dla kleryka in minoribus Stanisława z Zatora (sprzed 1524 roku) oraz wzmianka o elekcji i koronacji papieża Klemensa VII (odpowiednio 19 i 23 listopada 1523 roku).

46 A. Wagner, Superekslibris polski, passim.

47 A. Wagner, Prymas Maciej Drzewicki..., s. 41, przyp. 33 (tam odniesienia do dalszej literatury).

48 Już po złożeniu tekstu do druku okazało się, że w Archiwum Archidiecezjalnym w Poznaniu znajduje się egzemplarz Missale Posnaniensis, Kraków: J. Haller, 1524, 4o, oznaczony superekslibrisem niemal identycznym w formie, jak opisywany tu ekslibris (sygn. AAP $2133-$ na księgę zwrócił mi uwagę mgr Radosław Franczak z Instytutu Historii UAM, za co mu w tym miejscu bardzo dziękuję). Ów znak, jak i rękopiśmienne marginalia wskazują, że mszał należał do J. Żdżarowskiego. Można więc wnioskować, że początkowo znak notarialny stał się z czasem dla Żdżarowskiego pełnowartościowym księgoznakiem, użytym także w funkcji superekslibrisu.

\section{ROCZNIKI BIBLIOTECZNE}

ROK LXIII, 2019

(C) for this edition by CNS 
ANEKS

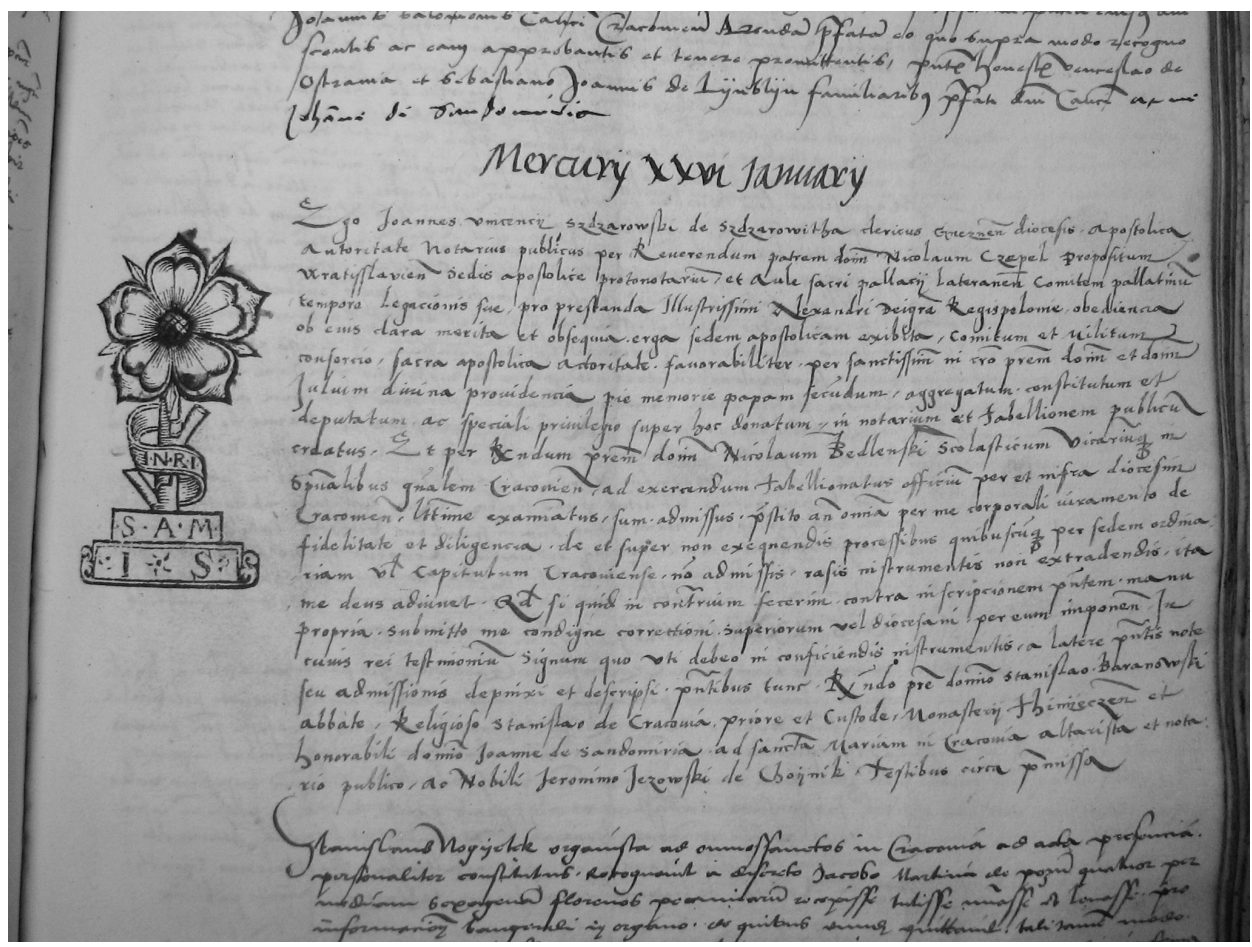

Il. 3. Wpis admisyjny J. Żdżarowskiego (Kraków, AKMK, AOff. 37, s. 665, fot. J. Łukaszewski)

Kraków, 26 stycznia 1519 roku

Admisja notarialna Jana Żdżarowskiego, syna Wincentego ze Żdżarowity ${ }^{49}$.

Kraków, Archiwum Kurii Metropolitalnej, Acta Officialia (Acta Actorum Vicarialia), AOff. 37, s. 665. Po lewej stronie zapiski znak notarialny, odbity za pomocą klocka drzeworytniczego: na dwu gradusach na łodydze róża — godło herbu Poraj; łodyga opleciona jest wstęgą, w której umieszczony został monogram antykwą $I[$ esus $] N[$ azarenus $] R[$ ex $] I[$ udaeorum $]$. W dolnym gradusie inicjały antykwą I[oannes] $S[$ zdzarowski], na górnym S[ignum] A[uthenticum] M[eum]. We wstędze rozmiar odbitki: $60 \times 32 \mathrm{~mm}$.

49 Edycja tekstu przygotowana zasadniczo na podstawie A. Wolff, Projekt instrukcji wydawniczej dla pisanych źródet historycznych do połowy XVI wieku, „Studia Źródłoznawcze” 1, 1957, s. $155-181$. 


\section{[1519] Mercurii XXVI Januarii}

Ego Joannes Vincencii Szdzarowski de Szdzarowitha ${ }^{50}$, clericus Gneznensis diocesis, apostolica autoritate notarius publicus, per Reverendum patrem dominum Nicolaum Czepel $^{51}$, prepositum Wratisslaviensem, Sedis Apostolice protonotarium et Aule Sacri Pallacii Lateranensis comitem pallatinum tempore legacionis sue pro prestanda Illustrissimi Alexandri Dei gracia Regis Polonie obediencia, ob eius clara, merita et obsequia erga Sedem Apostolicam exibita, Comitum et Militum consorcio, sacra apostolica actoritate, favorabiliter per sanctissimum in Cristo patrem, dominum et dominum Julium divina providencia pie memorie papam secundum aggregatum, constitutum et deputatum, ac speciali privilegio super hoc donatum, in notarium et tabellionem publicum creatus. Et per Reverendum patrem dominum Nicolaum Bedlenski ${ }^{52}$, scolasticum vicariumque in spiritualibus generalem Cracoviensem, ad exercendum tabellionatus officium per et infra diocesim Cracoviensem, legittime examinatus, sum admissus, prestito ante omnia per me corporali iuramento de fidelitate et diligencia, de et super non exequendis processibus quibuscumque, per sedem ordinariam vel Capitulum Cracoviense, non admissis, rasis instrumentis non extradendis, ita me Deus adiuvet. Quod si quid in contrarium fecerim contra inscripcionem presentem manu propria submitto me condigne correctioni superiorum vel diocesani, per eum imponende. In cuius rei testimonium signum, quo uti debeo in conficiendis instrumentis, a latere presentis note seu admissionis depinxi et descripsi.

Presentibus tunc Reverendo patre, domino Stanislao Baranowski abbate ${ }^{53}$, Religioso Stanislao de Cracovia priore et custode Monasterii Thinyeczensis ${ }^{54}$ et honorabili domino Joanne de Sandomiria ad Sanctam Mariam in Cracovia altarista et notario publico ${ }^{55}$, ac Nobili Jeronimo Jezowski de Choynik ${ }^{56}$, testibus circa premissa.

50 Zob. przyp. 7.

${ }^{51}$ Zob. przyp. 14.

52 Mikołaj z Bedlna (-1540) — scholastyk katedralny krakowski, kanonik poznański, gnieźnieński, wikariusz generalny krakowski; por. J. Krzemieniecki, Bedleński Mikołaj z Bedlna, [w:] PSB, T. 1. Abakanowicz Abdank Bruno-Beynart Wojciech, Kraków 1935, s. 395.

53 Stanisław Baranowski (około 1460-1526) — opat tyniecki w latach 1512-1526; por. P. Sczaniecki, Katalog opatów tynieckich, „Nasza Przeszłość” 49, 1978, s. 116-119.

54 Stanisław z Krakowa (-1551) — pochodzenia mieszczańskiego, przeor i kustosz tyniecki, od 1531 roku opat w Starych Trokach; por. T.M. Trajdos, Benedyktyni w Starych Trokach (XV-potowa XVII w.), „Lituano-Slavica Posnaniensia: studia historica” 12, 2007, s. 245.

55 Jan, syn Mikołaja, z Sandomierza - kleryk diecezji krakowskiej, notariusz publiczny, altarysta kościoła NMP w Krakowie, możliwe, że tożsamy z Janem, synem Mikołaja, zapisanym na Uniwersytet Krakowski w 1519 roku (por. Metryka czyli album Uniwersytetu Krakowskiego z lat 1509-1551. Biblioteka Jagiellońska rkp. 259, wyd. A. Gąsiorowski, T. Jurek, I. Skierska, przy współpracy R. Grzesika, Warszawa 2010.

56 Hieronim Jeżowski z Chojnika (zmarł przed 1527 rokiem) — w latach 1521-1531 sołtys w Chojniku (parafia Gromnik), ławnik sądu wyższego prawa niemieckiego w Goleszu; por. F. Si- 


\section{BIBLIOGRAFIA}

\section{ŹRÓDŁA RĘKOPIŚMIENNE}

Gniezno, Archiwum Archidiecezjalne, sygn. ACons.GII.

Kraków, Archiwum Kurii Metropolitalnej, sygn. AOff. 37, AOff. 57.

Poznań, Archiwum Archidiecezjalne, sygn. AE VII, AE X.

Poznań, Archiwum Państwowe, Księgi sądu i urzędu grodzkiego w Poznaniu, sygn. Gr. 16.

\section{INKUNABUŁY, STARE DRUKI}

\section{Gniezno, Archiwum Archidiecezjalne}

Formularium instrumentorum ad usum Curiae Romanae, [Hagenau: Heinrich Gran, przed 17 VIII 1492?], in $4^{\circ}$, sygn. Inc. 37.

Formulare Instrumentorum, Köln: H. Quentell, 1504, 4º, sygn. BK 5605.

Poznań, Biblioteka Uniwersytecka

Stöffler Johann, Ephemeridum [...] a capite anni redemptoris Christi MDXXXII in alios XX. proxime subsequentes, Tybinga: H. Mohart, 1531, $4^{\circ}$, sygn. SD 6660II.

Poznań, Biblioteka Poznańskiego Towarzystwa Przyjaciół Nauk

Johannes Chrysostomus, Index in Quinque Tomos operum..., Basel: A. Cratander, 1522, $2^{\circ}$, sygn. 47941, T. 3.

\section{ŹRÓDŁA WYDANE}

Acta capitulorum nec non iudiciorum ecclesiasticorum selecta, T. 2. Acta iudiciorum ecclesiasticorum dioecesum Gneznensis et Poznaniensis (1403-1530), wyd. B. Ulanowski, Kraków 1902.

Acta Historica Res Gestas Poloniae illustrantia ab anno 1507 usque ad annum 1795, T. 1. Andrzeja na Więcborku Zebrzydowskiego Biskupa włocławskiego i krakowskiego korespondencyja z lat 1546-1553 z przydaniem Synodów r. 1547 i 1551, jako też innych dokumentów wspótczesnych, wyd. W. Wisłocki, Kraków 1878.

Akta kapituł z wieku XVI wybrane, wyd. B. Ulanowski, T. 1, cz. 1. Akta kapituł poznańskiej i włoctawskiej (1519-1578), Kraków 1908.

Acta Tomiciana, T. 14, wyd. W. Pociecha, Wrocław-Kraków 1952.

Acta Tomiciana, T. 15, wyd. W. Pociecha, Wrocław-Kraków 1957.

Acta Tomiciana, T. 16, cz. 2, wyd. W. Pociecha, Wrocław-Kraków-Poznań 1961.

Jana Żdżarowskiego, kanonika poznańskiego diariusz z lat 1532-1551, wyd. R. Wójcik, W. Wydra, Poznań 2009.

Matricularum Regni Poloniae Summaria, wyd. T. Wierzbowski, cz. 4, T. 2, Warszawa 1912.

Metryka czyli album Uniwersytetu Krakowskiego z lat 1509-1551. Biblioteka Jagiellońska rkp. 259, wyd. A. Gąsiorowski, T. Jurek, I. Skierska, przy współpracy R. Grzesika, Warszawa 2010.

Najstarsza ksiega promocji Wydziatu Sztuk Uniwersytetu Krakowskiego z lat 1404-1541, wyd. A. Gąsiorowski, T. Jurek, I. Skierska, Warszawa 2011.

Vetera Monumenta Poloniae et Lithuaniae, T. 2, wyd. A. Theiner, Roma 1891.

kora, Chojnik, [w:] Stownik historyczno-geograficzny województwa krakowskiego w średniowie$c z u$, cz. 1, z. 2. Borek-Ciecień, oprac. Z. Leszczyńska-Skrętowa, F. Sikora, J. Wiśniewski, Wrocław-Warszawa-Kraków 1985, s. 354; M. Wolski, Lichwin, [w:] Słownik historyczno-geograficzny województwa krakowskiego w średniowieczu, cz. 3, z. 3. Lasocice-Łaganów, oprac. W. Bukowski et al., Kraków 2000, s. 620.

\section{ROCZNIKI BIBLIOTECZNE}

ROK LXIII, 2019

(C) for this edition by CNS 


\section{LITERATURA}

Barycz H., Czepiel (Czepel) Mikołaj (1453-1518), [w:] Polski Stownik Biograficzny, T. 4. Chwalczewski Jerzy-Dąbrowski Ignacy, Kraków 1938, s. 331-332.

Chodyński S., Katalog prałatów i kanoników włocławskich, cz. 5. T-Z, Włocławek 1914 [rkps; kopia z 1994 r. w zbiorach Biblioteki Seminarium Duchownego we Włocławku, bez sygn.].

Chwalewik E., Exlibrisy polskie szesnastego i siedemnastego wieku, Wrocław 1955.

Dembiński P., Poznańska kapituła katedralna schyłku wieków średnich. Studium prozopograficzne 1428-1500, Poznań 2012.

Dobrzyńska-Rybicka L., Dwie wielkopolskie bibljoteki klasztorne, „Zapiski Muzealne” 1918, nr 2-3, s. 3-29.

Fiutak A., Prałaci kanonicy kruszwiccy, Popowo Kościelne 1938 (maszynopis).

Formanowicz L., Katalog inkunabułów Biblioteki Katedralnej w Gnieźnie, z. 1, Poznań 1939.

Frenz T., Die Kanzlei der Päpste der Hochrenaissance (1471-1527), Tübingen 1986.

Gesamtkatalog der Wiegendrucke, T. 9, Stuttgart 1991.

Graf zu Leningen-Westerburg K.E., Bibliothekzeichen Exlibris. Ein Handbuch für Sammler Bücher- und Kunstfreunde, Stuttgart 1901.

Gąsiorowski A., Admisje notariuszy publicznych w Wielkopolsce u schyłku wieków średnich, [w:] Społeczeństwo Polski średniowiecznej, T. 5, pod red. S.K. Kuczyńskiego, Warszawa 1992, s. 267-275.

Gąsiorowski A., Notariusze publiczni w Wielkopolsce u schyłku wieków średnich. Katalog admisji w Gnieźnie i w Poznaniu 1420-1500, Poznań 1993.

Grońska M., Ekslibrisy: wiadomości zebrane dla kolekcjonerów, Warszawa 1992.

Incunabula quae in bibliothecis Poloniae asservantur, T. 1, moderante Alodia Kawecka-Gryczowa composuerunt Maria Bohonos et Elisa Szandorowska, Wratislaviae 1970.

Iwańska-Cieślik B., Aspekty badań nad księgozbiorami członków kapituly katedralnej we Włoctawku, „Studia Włocławskie” 13, 2011, s. 189-203.

Knapek E., Akta oficjalatu i wikariatu generalnego krakowskiego do połowy XVI wieku, Kraków 2010.

Koczerska M., De manu, signo et nomine, czyli o krakowskich notariuszach publicznych w późnym średniowieczu, [w:] Kultura średniowieczna i staropolska. Studia ofiarowane Aleksandrowi Gieysztorowi w pięćdziesięciolecie pracy, pod red. D. Gawinowej, S. Gawlasa, M. Koczerskiej, Warszawa 1991, s. 191-206.

Kolb A., Ein Exlibris des 15. Jahrhunderts? Zur Geschichte der ältesten fränzösischen Bücherzeichen, „Gutenberg-Jahrbuch” 36, 1961, s. 249-254.

Krzemieniecki J., Bedleński Mikołaj z Bedlna, [w:] Polski Słownik Biograficzny, T. 1. Abakanowicz Abdank Bruno-Beynart Wojciech, Kraków 1935, s. 395.

Lewicka-Kamińska A., Renesansowy księgozbiór Mikołaja Czepla w Bibliotece Jagiellońskiej, Wrocław 1956.

Lutyński K., Kapituła katedralna w Poznaniu w XVI wieku. Organizacja i majątek, Poznań 2000.

Miaskowski K., Kanonicy katedralni poznańscy instalowani w latach 1524-1532, „Przegląd Kościelny" 6, 1904, nr 34, s. 276-281.

Müller B., Notariatssignet und Exlibris, „Exlibriskunst und Graphik” 1989, s. 15-20.

Nowacki J., Dzieje Archidiecezji Poznańskiej, T. 2. Archidiecezja Poznańska w granicach historycznych i jej ustrój, Poznań 1964.

O’Dell I., Deutsches und Österreichische Exlibris 1500-1599 im Britischen Museum, London 2003.

Osięgłowski J., Konserwacja ksiązki w Polsce przedrozbiorowej, Poznań 1985.

Schuler P.J., Südwestdeutsche Notarszeichen. Mit einer Einleitung über die Geschichte der deutschen Notarszeichens, Sigmaringen 1978. 
Sczaniecki P., Katalog opatów tynieckich, „Nasza Przeszłość” 49, 1978, s. 5-244.

Sikora F., Chojnik, [w:] Słownik historyczno-geograficzny województwa krakowskiego w średniowieczu, cz. 1, z. 2. Borek-Ciecień, oprac. Z. Leszczyńska-Skrętowa, F. Sikora, J. Wiśniewski, Wrocław-Warszawa-Kraków-Gdańsk-Łódź 1985, s. 353-354.

Skupieński K., Notariat publiczny w średniowiecznej Polsce, Lublin 1997.

Tomczak A., Kancelaria biskupów włocławskich w okresie księgi wpisów (XV-XVIII w.), „Roczniki Towarzystwa Naukowego w Toruniu" 71, 1965, z. 1, s. 1-275.

Trajdos T.M., Benedyktyni w Starych Trokach (XV-połowa XVII w.), „Lituano-Slavica Posnaniensia: studia historica" 12, 2007, s. 203-249.

Ulanowski B., Materyaty do historyi prawa i heraldyki polskiej, „Archiwum Komisji Historycznej" 3, 1886, s. 271-471.

Wójcik R., Wydra W., Jana Żdżarowskiego, kanonika poznańskiego, diariusz z lat 1532-1551, „Kronika Miasta Poznania" 2006, nr 4. Literackie przystanki, s. 43-61.

Wagner A., Prymas Maciej Drzewicki jako bibliofil. W pięćsetlecie powstania pierwszego polskiego ekslibrisu, Warszawa-Toruń-Poznań-Drzewica 2016.

Wagner A., Superekslibris Polski. Studium o kulturze bibliofilskiej i sztuce od średniowiecza do połowy XVII wieku, Toruń 2016.

Wagner A., Uwagi o znakach własnościowych z drugiej połowy XVI i pierwszej ćwierci XVI wieku w inkunabułach Biblioteki Uniwersyteckiej w Poznaniu, „Biblioteka” 17 (26), 2013, s. 7-35.

Wolff A., Projekt instrukcji wydawniczej dla pisanych źródeł historycznych do połowy XVI wieku, „Studia Źródłoznawcze” 1, 1957, s. 155-181.

Wolski M., Lichwin, [w:] Słownik historyczno-geograficzny województwa krakowskiego w średniowieczu, cz. 3, z. 3. Lasocice-Laganów, oprac. W. Bukowski, J. Kurtyka, J. Laberschek, Z. Leszczyńska-Skrętowa, F. Sikora, M. Wolski, Kraków 2000, s. 617-621.

JAKUB ŁUKASZEWSKI

\section{ON JAN ŻDŻAROWSKI AND HIS NOTARIAL SIGN USED UNTYPICALLY AS A BOOKPLATE}

\section{Summary}

The oldest Polish bookplate known today and imprinted directly from a woodcut block on book pages is one attributed to Wojciech Strzałkowski, a notary from Gniezno (dated to 15191520). It can be found in an incunabulum from the collection of the Cathedral Library in the Archdiocesan Archives in Gniezno (Formularium instrumentorum ad usum Curiae Romanae [Hagenau: Heinrich Gran, before 17 August 1492], in $4^{\circ}$, no. Inc. 37). In the article the author demonstrates that the sign in fact belonged to Jan Żdżarowski (-1551), a public notary as well as canon of Poznań, Włocławek and Kraków. In his notarial admission (of 26 January 1519) Żdżarowski used a woodcut block to make his notarial sign (at that time notaries usually drew their signs). He used the same block to make a bookplate. An analysis of the state of preservation of both prints demonstrates that the block used to make them originated around 1517-1518, certainly before 26 January 1519 , perhaps in Kraków. This is the oldest known case of a block being used to make a notarial sign by a notary from Poland and, at the same time, the first case of the same tool being used also to make a bookplate. The annex features an edition of the text of Jan Żdżarowski's admission.

KEY WORDS: notarial sign, bookplate, woodcut block, Jan Żdżarowski, Wojciech Strzałkowski, early printed books, incunabula

\section{ROCZNIKI BIBLIOTECZNE}

ROK LXIII, 2019

(C) for this edition by CNS 